\title{
Professional BURNOUT OF PRE-SCHOOL AND EARLY-SCHOOL TEACHERS
}

\author{
WYPALENIE ZAWODOWE NAUCZYCIELEK \\ EDUKACJI PRZEDSZKOLNEJ I WCZESNOSZKOLNEJ
}

\begin{abstract}
The aim of this article is an empirical verification of the problem of burnout of pre-school and early-school education teachers.

Material and methods

Empirical material, author's material collected on the basis of a survey of 182 people. It consists of 19 questions: five examined the dimension of emotional exhaustion, seven examined the dimension of depersonalization and seven more related to the sense of personal achievement. The teachers surveyed had to refer to a four-step scale (from 1 - completely inappropriate for me to 4 - definitely suitable for me). The second part of the questionnaire was used to measure the level of self-assessment. Self-assessment was measured based on the Polish adaptation of the SES M Self-Assessment Scale. Rosenberg.
\end{abstract}

\section{Results}

The teachers of pre-school education and early school education were characterized by different levels of professional burnout. The low level of burnout was represented by $29.7 \%$ of the respondents, the average by $41.7 \%$, and the high by $28.6 \%$.

\section{Conclusions}

The relation between the level of education (pre-school, early-school), the age of the respondents, their length of service, the level of education and professional burnout does not allow to plot a permanent trend in the studied group, a relation which allows to unambiguously interpret the results obtained. Socio-demographic factors also do not have a high impact on the self-esteem of the studied group of female 
teachers. There are no noticeable differences between individual subgroups and the index value of the self-assessment variable. The vast majority (72\%) of the teachers surveyed achieved average and above-average results in the SES Rosenberg self-assessment test. What can be said after verification of the hypotheses is that female teachers with higher seniority had higher self-assessment results obtained with the Rosenberg SES self-assessment test.

\section{STRESZCZENIE}

Celem prezentowanego artykułu jest empiryczna weryfikacja problemu wypalenia zawodowego nauczycielek wychowania przedszkolnego i edukacji wczesnoszkolnej.

\section{Material i metody}

Materiał empiryczny, autorski zebrany na podstawie ankietyzacji 182 osób. Test wypalenia zawodowego został opracowany samodzielnie. Składa się on z 19 pytań: pięć badało wymiar wyczerpania emocjonalnego, siedem badało wymiar depersonalizacji, a kolejnych siedem odnosiło się do poczucia osiągnięć osobistych. Badane nauczycielki musiały odnieść się z zastosowaniem czterostopniowej skali (od 1 - zupełnie do mnie nie pasuje, do 4 - zdecydowanie do mnie pasuje). Druga część użytego kwestionariusza służyła do pomiaru poziomu samooceny. Samoocena została zmierzona na podstawie polskiej adaptacji Skali Samooceny SES M. Rosenberga.

\section{Wyniki}

Badane nauczycielki wychowania przedszkolnego i edukacji wczesnoszkolnej charakteryzowały się zróżnicowanym poziomem wypalenia zawodowego. Niski poziom wypalenia reprezentowało $29,7 \%$ badanych, przeciętny $41,7 \%$, wysoki zaś $28,6 \%$.

\section{Wnioski}

Zależność pomiędzy poziomem kształcenia (przedszkolny, wczesnoszkolny), wiekiem badanych, ich stażem pracy, poziomem wykształcenia a wypaleniem zawodowym nie pozwala $w$ badanej grupie na wykreślenie trwałego trendu, zależności pozwalającej jednoznacznie zinterpretować uzyskane wyniki. Czynniki socjo-demograficzne nie mają również wysokiego wpływu na samoocenę badanej grupy nauczycielek. Nie ma zauważalnych różnic między poszczególnymi podgrupami a wartością wskaźnikową zmiennej samoocena. Znakomita większość (72\%) badanych nauczycielek osiągnęła przeciętne i ponadprzeciętne wyniki w teście samooceny SES Rosenberga. Po weryfikacji hipotez można stwierdzić, że nauczycielki z wyższym stażem pracy miały wyższe wyniki samooceny uzyskane testem SES Rosenberga.

KEYWORDS: professional burnout, teachers, self-assessment, multidimensional scaling, factor analysis

SŁOWA KLUCzowE: wypalenie zawodowe, nauczycielki, samoocena, skalowanie wielowymiarowe, analiza czynnikowa 


\section{WPROWADZENIE}

Problematyka wypalenia zawodowego funkcjonuje w naukach społecznych od blisko 40 lat. Wprowadziła ją do obiegu naukowego Christina Maslach. Wypaleniu zawodowemu poświęcono wiele badań. Mimo to ciągle jest aktualna i nie zapowiada się, by szybko ten problem został rozwiązany w sposób systemowy.

\section{CEl i PROBlematyKa BADAWCZA}

Głównym celem przedstawionego artykułu jest empiryczne rozpoznanie zjawiska wypalenia zawodowego u nauczycielek wychowania przedszkolnego i edukacji wczesnoszkolnej oraz ustalenie związków komponentów wypalenia zawodowego $\mathrm{z}$ samooceną oraz ze zmiennymi społeczno-demograficznymi.

Ogólne pytanie badawcze brzmi: czy i jakie różnice w poziomie wypalenia zawodowego nauczycielek definiowane w trzech obszarach występują u osób o określonych cechach demograficznych, społecznych oraz o określonym poziomie samooceny?

\section{Pytania BadAWCZE}

Przedstawione badania osadzone są $\mathrm{w}$ paradygmacie pozytywistycznym, a zastosowane techniki analizy materiału badawczego są typowe dla badań ilościowych.

Do celów metodologicznych wyodrębniono następujące pytania badawcze szczegółowe:

1. Jaki jest związek między typem placówki oświatowej, w jakiej pracują badane nauczycielki, a poszczególnymi wymiarami wypalenia zawodowego?

2. W jakim stopniu wiek badanych determinuje poszczególne wymiary wypalenia zawodowego nauczycielek?

3. W jakim stopniu staż pracy determinuje poszczególne wymiary wypalenia zawodowego nauczycielek?

4. W jakim stopniu posiadane wykształcenie determinuje poszczególne wymiary wypalenia zawodowego nauczycielek?

5. W jakim stopniu posiadany stopień awansu zawodowego determinuje poszczególne wymiary wypalenia zawodowego nauczycielek? 
16. W jakim stopniu lokalizacja placówki oświatowej determinuje poszczególne wymiary wypalenia zawodowego nauczycielek?

17. W jakim stopniu rodzaj placówki oświatowej, w jakiej pracują nauczycielki, determinuje poziom samooceny nauczycielek?

18. W jakim stopniu wiek determinuje poziom samooceny nauczycielek?

19. W jakim stopniu staż pracy determinuje poziom samooceny nauczycielek?

10. W jakim stopniu posiadane wykształcenie determinuje poziom samooceny nauczycielek?

11. W jakim stopniu posiadany stopień awansu zawodowego wpływa na poziom samooceny nauczycielek?

12. W jakim stopniu lokalizacja placówki oświatowej determinuje poziom samooceny nauczycielek?

13. Jaki jest związek między poziomem samooceny badanych nauczycielek a poszczególnymi wymiarami wypalenia zawodowego?

\section{METODA, TECHNIKA, NARZĘDZIE BADAWCZE}

Metodą, jaką posłużono się do przeprowadzenia badań, był sondaż diagnostyczny. Służy on przede wszystkim do badania opinii i poglądów w określonej grupie społecznej czy zawodowej. W tych konkretnych badaniach w grupie znalazły się nauczycielki edukacji początkowej ze szkół podstawowych i wychowawczynie-nauczycielki edukacji przedszkolnej.

Techniką, którą zastosowano, była ankieta. Zaprojektowane narzędzie składało się z trzech części. Pierwsza część mierzyła poziom poczucia wypalenia zawodowego z podziałem na: wyczerpanie emocjonalne, depersonalizację oraz ocenę kompetencji i dokonań zawodowych. Przy tworzeniu narzędzia oparto się na trójwymiarowym modelu wypalenia zawodowego Christiny Maslach. Jednak test wypalenia zawodowego został opracowany samodzielnie. Składa się on z 19 pytań. Inaczej niż to zrobiła C. Maslach, w opracowanym teście pięć badało wymiar wyczerpania emocjonalnego, siedem badało wymiar depersonalizacji, a kolejnych siedem odnosiło się do poczucia osiągnięć osobistych. Badane nauczycielki musiały odnieść się z zastosowaniem czterostopniowej skali (od 1 - zupełnie do mnie nie pasuje, do 4 - zdecydowanie do mnie pasuje). Oryginalny kwestionariusz MBI autorstwa Christiny Maslach składał się z 22 pozycji testowych, z których dzie- 
więć badało wymiar wyczerpania emocjonalnego, pięć badało wymiar depersonalizacji, a osiem odnosiło się do poczucia osiągnięć osobistych. Użyta przez Maslach skala pomiarowa posiadała siedem stopni od 0 (nigdy) do 6 (codziennie) (podaję za: Plichta 2015, s. 101).

Druga część użytego kwestionariusza służyła do pomiaru poziomu samooceny. Samoocena została zmierzona w oparciu na polską adaptację Skali Samooceny SES M. Rosenberga. Jest to test przeznaczony do badania poziomu ogólnej samooceny. Skala Samooceny SES M. Rosenberga w polskiej adaptacji I. Dzwonkowskiej, K. Lachowicz-Tabaczek i M. Łaguny składa się z 10 twierdzeń, którym przypisana jest czterostopniowa skala (od 1 - zdecydowanie zgadzam się, do 4 - zdecydowanie nie zgadzam się). Wartość współczynnika rzetelności polskiej wersji metody w różnych badanych grupach wahała się od 0,81 do 0,83 . Zespół adaptacyjny stwierdził satysfakcjonującą stabilność narzędzia. Wyniki badań z wykorzystaniem polskiej adaptacji Skali Samooceny SES Rosenberga potwierdzają jej wysoką trafność.

W trzeciej części umieszczono opisujące status zatrudnienia, wiek, staż pracy, poziom wykształcenia, wymiar czasu pracy, stopień awansu zawodowego, typ szkoły oraz miejsce pracy.

\section{PrZEDMIOT BADANIA I CHARAKTERYSTYKA BADANYCH}

Przedmiotem badań naukowych jest określony zbiór zjawisk, procesów, osób lub przedmiotów w odniesieniu do pytań badawczych. Za przedmiot tych badań obrano poczucie wypalenia zawodowego nauczyciela i poziom samooceny.

W przeprowadzonych badaniach wzięło udział 182 kobiet-nauczycielek czynnych zawodowo, pracujących na terenie województwa mazowieckiego. Badana grupa była zróżnicowana pod względem miejsca pracy. Prawie w połowie były to nauczycielki wychowania przedszkolnego (47,3\%), natomiast druga połowa $(52,7 \%)$ to nauczycielki nauczania początkowego. Przedział wiekowy badanych nauczycielek mieścił się miedzy 25. a 45. rokiem życia. Dominowały osoby w wieku 25-35 lat (67\%). Staż pracy mieścił się w przedziale między 1. rokiem a 20 latami pracy. Najliczniejszą grupę stanowiły nauczycielki o stażu pracy od 6 do 10 lat (47\%) oraz 11 do 15 lat (36\%). 


\section{STATYSTYCZNE OPRACOWANIE WYNIKÓW BADAŃ}

Do analizy statystycznej użyto pakietu statystycznego SPSS w wersji 25.

O użyciu testów weryfikujących hipotezy badawcze zadecydował wynik testu pozwalającego na ocenę normalności rozkładu empirycznego z rozkładem teoretycznym. Do tego celu stosuje się testy Shapiro-Wilka (W) lub Kołmogorowa-Smirnowa (K-S). Oba te testy znajdują się w procedurze EXAMINE pakietu SPSS.

Zatem na początku analizy danych dokonano sprawdzenia zgodności rozkładu zmiennych użytych $\mathrm{w}$ analizie problemu badawczego z rozkładem normalnym. Okazało się, że żadna $z$ analizowanych zmiennych nie spełniła kryterium normalności weryfikowanego testem W. Shapiro-Wilka. Zatem nie mogły w dalszej analizie wchodzić w grę statystyki parametryczne. Dlatego też do dalszych analiz, a zwłaszcza weryfikacji hipotez roboczych, zostały zastosowane statystyki nieparametryczne, analizy oparte na tabelach kontyngencyjnych, współczynnik korelacji r Pearsona oraz procedury redukcji wymiarów (analiza czynnikowa) i analizy rzetelności (współczynnik zgodności wewnętrznej alfa Cronbacha). Przyjęty dla $\mathrm{r}$ Pearsona poziom istotności wynosi równy, mniejszy 0,05. Do analizy rozkładów odpowiedzi najmniej i najbardziej wypalonych nauczycielek wykorzystany został test chi².

Zmienne niezależne opisujące badane nauczycielki miały różną strukturę. Część miała charakter dychotomiczny i do weryfikowania pytań badawczych $\mathrm{z}$ ich zastosowaniem użyto testu U. Manna-Whitney'a. Jest on najmocniejszą alternatywą dla testu $t$ (Studenta) dla dwóch prób niezależnych. Jego interpretacja jest zasadniczo taka sama jak testu $t$ (Studenta) dla dwóch prób niezależnych. Dla weryfikowania pytań badawczych, gdzie zmienne niezależne przybierają trzy lub więcej wartości, zastosowano test $\mathrm{H}$. Kruskala-Wallisa - test ten jest określany przez niektórych badaczy jako ANOVA Kruskala-Wallisa dla zmiennych niespełniających założenia o jednorodności wariancji i rozkładu normalnego. Także w przypadku tego testu jego interpretacja jest identyczna jak testu t (Studenta) dla $k$ prób niezależnych czy parametrycznej jednoczynnikowej ANOV-y.

Szczególnie przydatne do przeprowadzenia analiz statystycznych okazały się dwie publikacje specjalnie dedykowane oprogramowaniu statystyczne- 
mu SPSS. Pierwsza to Statystyczny drogowskaz. Praktyczny poradnik analizy danych w naukach społecznych na przykładach $z$ psychologii pod redakcją S. Bedyńskiej i A. Brzezickiej (2007) oraz Statystyczny drogowskaz 2. Praktyczne wprowadzenie do analizy wariancji pod redakcją S. Bedyńskiej i M. Cypryańskiej (2013).

W celu określenia wewnętrznej struktury zastosowanego narzędzia użyto analizy czynnikowej z zastosowaniem rotacji Varimax. Procedura ta pozwoliła wyodrębnić trzy wymiary. Łącznie wszystkie trzy czynniki wyjaśniają $68,93 \%$ wariancji. Miara K-M-O adekwatności doboru próby wyniosła 0,888 , a Test Sferyczności Bartletta $=2659,255(\mathrm{df}=171), \mathrm{p}=0,000$.

\section{Wypalenie emocjonalne}

Zastosowane pięcioitemowego narzędzia opisującego wymiar wypalenia emocjonalne okazało się bardzo trafnym zabiegiem badawczym. Okazał się on narzędziem jednowymiarowym. Analiza czynnikowa z zastosowaniem rotacji Varimax pozwoliła wyodrębnić ten czynnik jako pierwszy. Czynnik ten wyjaśnia 45,93\% wariancji. Analiza rzetelności z zastosowaniem współczynnika alfa Cronbacha pokazała, że wszystkie itemy wchodzące w skład wymiaru wypalenia emocjonalne stanowią jeden spójny wymiar. Alfa Cronbacha $=0,836$.

\section{Depersonalizacja}

Zastosowanie siedmioitemowego narzędzia opisującego wymiar depersonalizacja okazało się również trafnym zabiegiem badawczym. Zastosowane stwierdzenia okazały się narzędziem jednowymiarowym. Analiza czynnikowa $\mathrm{z}$ zastosowaniem rotacji Varimax pozwoliła wyodrębnić ten czynnik jako drugi. Czynnik ten wyjaśnia 13,25\% wariancji, a analiza rzetelności z zastosowaniem współczynnika alfa Cronbacha pokazała, że wszystkie itemy wchodzące w skład komponentu depersonalizacja stanowią jeden spójny wymiar (Alfa Cronbacha $=0,829$ ).

\section{Zaangażowanie osobiste (ocena kompetencji i dokonań zawodowych)}

Zastosowanie siedmioitemowego narzędzia opisującego wymiar $z a$ angażowanie osobiste okazało się bardzo trafnym zabiegiem badawczym. 
Okazał się on narzędziem jednowymiarowym. Analiza czynnikowa z zastosowaniem rotacji Varimax pozwoliła wyodrębnić ten czynnik jako kolejny (czynnik ten wyjaśnia 9,77\% wariancji). Analiza rzetelności z zastosowaniem współczynnika alfa Cronbacha pokazała, że wszystkie itemy wchodzące w skład wymiaru zaangażowanie osobiste stanowią jeden spójny wymiar (Alfa Cronbacha $=0,918$ ).

\section{Wypalenie zawodowe w świetle analizy MDS}

Dodatkowo w analizie wyników wypalenia zawodowego zastosowano skalowanie wielowymiarowe (MDS), przeprowadzone za pomocą procedury PROXSCAL w programie SPSS 25.0. Jest to technika umożliwiająca analizę podobieństw między zmiennymi za pomocą graficznego przedstawienia tych zależności w przestrzeni zdefiniowanej przez określoną liczbę wymiarów. W skalowaniu wielowymiarowym zmienne traktowane są jako punkty i rozmieszczane w taki sposób, że odległości między nimi odpowiadają związkom między zmiennymi (Koseła, Utzig 1980). Dystans między zmiennymi zależy od ich korelacji - im wyższa korelacja, tym bliżej siebie są rozmieszczone punkty. Program przeprowadzający skalowanie wielowymiarowe znajduje określoną konfigurację odległości między zmiennymi, a następnie sprawdza, na ile dobrze odtwarza ona obserwowane wewnątrz danych relacje. Jako miarę trafności dopasowania wykorzystany jest wskaźnik Stress-1. Wartość wskaźnika Stress-1 dwuwymiarowego skalowania konfirmacyjnego opartego na wynikach 182 badanych nauczycielek wyniosła 0,069 , co świadczy o dobrej trafności dopasowania uzyskanej konfiguracji do obserwowanych danych. Wymiar 1, w jakich znalazły się zmienne opisujące wypalenie zawodowe, wyznaczają stwierdzenia: „Łatwo irytuję się” oraz „W swojej pracy jak dotąd niewiele osiągnęłam”. Wymiar 2 wyznaczają natomiast stwierdzenia "Zaniedbuję swoje obowiązki zawodowe” oraz „Praca zawodowa jest dla mnie źródłem stresu”.

Wynik zastosowania tej procedury przedstawia rysunek nr 1. 
Rysunek 1.

Wynik zastosowania procedury MSD

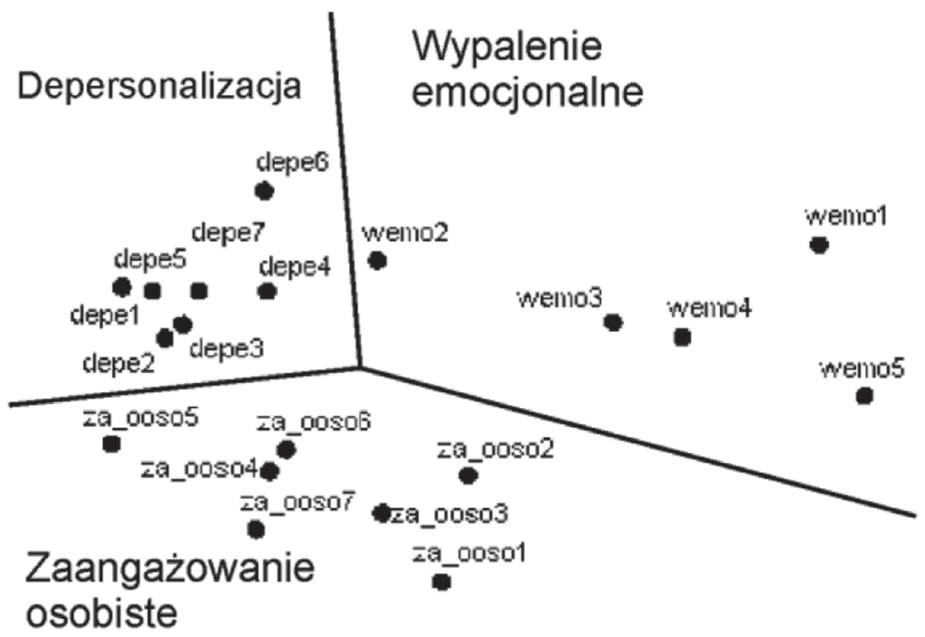

Źródło: opracowanie własne

Wypalenie zawodowe w'świetle analizy skupień hierarchicznych

Kolejną metodą poszukiwania podobieństw między obiektami (zmiennymi) jest analiza skupień tworzonych poprzez wykorzystanie miar odległości między obiektami. Metodę tę opisuje Tadeusz Marek (1989) oraz Czesław Noworol (1989). Analiza skupień stwarza możliwości klasyfikacji obiektów (w moim przypadku itemów) w grupy o znacznym stopniu podobieństwa (Rószkiewicz 2002, s. 288). Diagram drzewkowy skupień (dendogram) przedstawiony na rysunku 2 jest oparty na odległościach euklidesowych (metoda Warda) i pokazuje trzy oddzielne gałęzie. Pierwsza z nich, opisująca wypalenie emocjonalne, jest złożona $\mathrm{z}$ dwóch skupień utworzonych przez zmienne opisujące wymiar wypalenia emocjonalnego (wemo4, wemo3, wemo1 i wemo5), które ostatecznie łączą się w jedno odgałęzienie. Druga, opisująca zaangażowanie osobiste, również stworzona jest przez dwa skupienia. Pierwsze składa się ze zmiennych za_oso1 oraz za_oso2. Drugie skupia pięć pozostałych zmiennych opisujących wymiar zaangażowania osobistego. Trzecia gałąź jest złożona z trzech skupień. I opisuje wymiar depersonalizacji. Pierwsze skupienie zawiera trzy zmienne (depe1, depe2, depe3). 
Drugie skupienie tworzą dwie zmienne (depe5 i depe7), trzecie natomiast dwie pozostałe (depe4 i depe6). Do wymienionego skupienia depersonalizacji dołącza kolejna zmienna wemo2 („Przed wyjściem do pracy odczuwam zmęczenie”). Gałąź depersonalizacji łączy się z gałęzią zaangażowania osobistego. Obie te gałęzie (wymiary wypalenia zawodowego) na najwyższym poziomie agregacji łączą się z gałęzią trzecią odpowiadającą wypaleniu emocjonalnemu.

Rysunek 2.

Wynik zastosowania procedury hierarchicznej analizy skupień

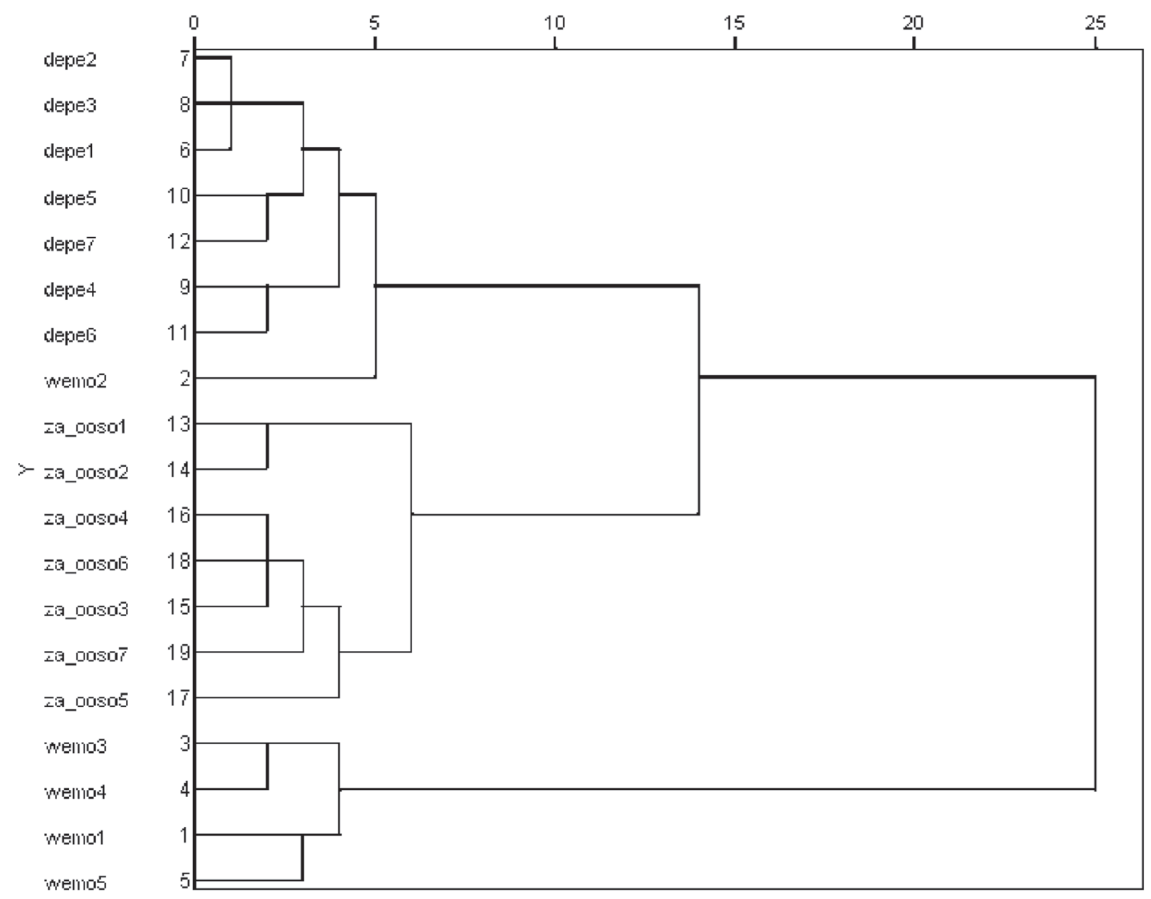

Źródło: opracowanie własne

\section{Samoocena}

Zastosowane narzędzie M. Rosenberga okazało się bardzo stabilnym i rzetelnym narzędziem. W przypadku badanych 182 nauczycielek okazało się ono narzędziem jednowymiarowym (pięć stwierdzeń zostało obróconych, 
zdekodowanych, tak by cała skala była logicznie zgodna). Analiza czynnikowa z zastosowaniem rotacji Varimax pozwoliła wyodrębnić jeden czynnik. Czynnik ten wyjaśnia 51,19\% wariancji. Miara K-M-O adekwatności doboru próby wyniosła 0,881, a Test Sferyczności Bartletta $=919,327(\mathrm{df}=45)$, $\mathrm{p}=0,000$. Analiza rzetelności z zastosowaniem współczynnika alfa Cronbacha pokazała, że wszystkie itemy wchodzące w skład SES Rosenberga stanowią jeden spójny czynnik. Alfa Cronbacha $=0,872$.

\section{WYNIKI BADAŃ WEASNYCH}

Badane nauczycielki wychowania przedszkolnego i edukacji wczesnoszkolnej charakteryzowały się zróżnicowanym poziomem wypalenia zawodowego. Niski poziom wypalenia reprezentowało $29,7 \%$ badanych, przeciętny $41,7 \%$, wysoki zaś $28,6 \%$. Granicę zjawiska wyznaczają dwie krańcowe wartości - (1) niskie wypalenie w trzech interesujących nas wymiarach oraz (2) wysokie wypalenie zawodowe. Oznaczenia te nie stanowią prostej sumy wartości przedziałowych, ale ich kombinację arytmetyczną, prostą, lecz bardzo obrazową. Kiedy jeszcze badacze posługiwali się pakietem OSIRIS III, znajdowała się w nim przydatna procedura COMBINE. Obecnie w SPSS trzeba radzić sobie inaczej. W tym konkretnym przypadku otrzymano 24 rozłączne kategorie opisowe. Jest to zmienna nominalna.

Kategorii absolutnie niskie wypalenie odpowiadała wartość całkowitego (sumarycznego) wypalenia zawodowego mieszczącego się w granicach 19 do 28 punktów. Nauczycielki te $(\mathrm{n}=14)$ można określić jako zaangażowane. Kategorii absolutnie przeciętne wypalenie zawodowe odpowiadała wartość całkowitego (sumarycznego) wypalenia zawodowego mieszczącego się w granicach od 35 do 43 punktów. Określić ją można jako zagrożone wypaleniem $(\mathrm{n}=16)$. Kategorii absolutnie wysokie wypalenie zawodowe odpowiadała wartość całkowitego (sumarycznego) wypalenia zawodowego mieszczącego się w granicach od 52 do 62 punktów. Nazwać je możemy jako całościowo wypalone $(\mathrm{n}=24)$.

Należy jednak zwrócić uwagę, że uzyskane wyniki co do całkowitego wypalenia różnią się, gdy je zestawimy z opisową wartością poszczególnych wymiarów. I tak niski poziom wypalenia zawodowego we wszystkich trzech wymiarach reprezentowało $7,7 \%$ badanych nauczycielek, przeciętny poziom 
uzyskało 8,8\% badanych, a wysoki 13,2\% badanych nauczycielek. Mimo że różnice tych wartości pomiędzy nauczycielkami wychowania przedszkolnego i nauczycielkami edukacji wczesnoszkolnej nie były istotne statystycznie, to niskim wypaleniem charakteryzowało się więcej nauczycielek edukacji wczesnoszkolnej (10,4\% wobec 4,7\% nauczycielek wychowania przedszkolnego). W przypadku przeciętnego i wysokiego wypalenia nieznacznie liczniej były reprezentowane nauczycielki wychowania przedszkolnego (9,3\% wobec $8,3 \%$ oraz $14 \%$ wobec $12,5 \%$ ).

W dalszej części rozdziału zostaną przedstawione uzyskane wyniki empiryczne istotne dla weryfikacji postawionych pytań badawczych. Ukazane zostaną zależności między zmiennymi socjo-demograficznymi, poczuciem wypalenia zawodowego i poziomem samooceny w całej grupie badanych nauczycieli.

\section{WYPALENIE ZAWODOWE - WERYFIKACJA PYTAŃ BADAWCZYCH}

\section{Rodzaj placówki a wypalenie zawodowe}

Na podstawie uzyskanych wyników (tabele 1-4) można wysnuć wniosek, że nauczycielki wychowania przedszkolnego we wszystkich trzech szczegółowych wymiarach wypalenia zawodowego oraz w wypaleniu całkowitym wykazują wyższy poziom tych wymiarów od nauczycielek edukacji wczesnoszkolnej, przy czym w przypadku zaangażowania osobistego $(\mathrm{U}=3186,0$; $\mathrm{p}=0,008)$ oraz całkowitego wypalenia $(\mathrm{U}=3222,0 ; \mathrm{p}=0,011)$ różnice są istotne statystycznie.

Tabela 1.

Wypalenie emocjonalne a typ placówki, w jakiej pracują badane nauczycielki

\begin{tabular}{|c|c|c|c|}
\hline Typ placówki & N & Średnia ranga & Suma rang \\
\hline Przedszkole & 86 & 97.97 & 8425.00 \\
\hline Szkoła podstawowa & 96 & 85.71 & 8228.00 \\
\hline Ogółem & 182 & & \\
\hline
\end{tabular}

Źródło: Opracowanie własne 
Tabela 2.

Depersonalizacja a typ placówki, w jakiej pracują badane nauczycielki

\begin{tabular}{|c|c|c|c|}
\hline Typ placówki & N & Średnia ranga & Suma rang \\
\hline Przedszkole & 86 & 98.97 & 8511.00 \\
\hline Szkoła podstawowa & 96 & 84.81 & 8142.00 \\
\hline Ogółem & 182 & & \\
\hline
\end{tabular}

Źródło: Opracowanie własne

Tabela 3.

Zaangażowanie osobiste a typ placówki, w jakiej pracują badane nauczycielki

\begin{tabular}{|c|c|c|c|}
\hline Typ placówki & N & Średnia ranga & Suma rang \\
\hline Przedszkole & 86 & 102.45 & 8811.00 \\
\hline Szkoła podstawowa & 96 & 81.69 & 7842.00 \\
\hline Ogółem & 182 & & \\
\hline
\end{tabular}

Źródło: Opracowanie własne

Tabela 4.

Całkowite wypalenie zawodowe a typ placówki, w jakiej pracują badane nauczycielki

\begin{tabular}{|c|c|c|c|}
\hline Typ placówki & N & Średnia ranga & Suma rang \\
\hline Przedszkole & 86 & 102.03 & 8775.00 \\
\hline Szkoła podstawowa & 96 & 82.06 & 7878.00 \\
\hline Ogółem & 182 & & \\
\hline
\end{tabular}

Źródło: Opracowanie własne

Badanie dostarcza dowodów, że nauczycielki pracujące w przedszkolu w większym stopniu są podatne na wypalenie zawodowe. 


\section{WIEK A WYPALENIE ZAWODOWE}

Przeprowadzone badanie dostarcza dowodów, że starsze wiekiem nauczycielki w większym stopniu są podatne na wypalenie zawodowe. $Z$ uzyskanych wyników (tabele 5-8) wynika, że nauczycielki w wieku 36-45 lat we wszystkich trzech szczegółowych wymiarach wypalenia zawodowego oraz w wypaleniu całkowitym wykazują wyższy poziom tych wymiarów od nauczycielek w wieku 26-35 lat, przy czym w przypadku wypalenia emocjonalnego $(\mathrm{U}=2334,0 ; \mathrm{p}=0,000)$, depersonalizacji $(\mathrm{U}=2772,0 ; \mathrm{p}=0,007)$ oraz całkowitego wypalenia $(\mathrm{U}=2574,0 ; \mathrm{p}=0,001)$ różnice są istotne statystycznie.

Tabela 5.

Wypalenie emocjonalne a wiek badanych nauczycielek

\begin{tabular}{|c|c|c|c|}
\hline Wiek & $\mathrm{N}$ & Średnia ranga & Suma rang \\
\hline $25-35$ lat & 122 & 80.63 & 9837.00 \\
\hline $36-45$ lat & 60 & 113.60 & 6816.00 \\
\hline Ogółem & 182 & & \\
\hline
\end{tabular}

Źródło: Opracowanie własne

Tabela 6.

Depersonalizacja a wiek badanych nauczycielek

\begin{tabular}{|c|c|c|c|}
\hline Wiek & N & Średnia ranga & Suma rang \\
\hline $25-35$ lat & 122 & 84.22 & 10275.00 \\
\hline 36 do 45 lat & 60 & 106.30 & 6378.00 \\
\hline Ogółem & 182 & & \\
\hline
\end{tabular}

Źródło: Opracowanie własne

Tabela 7.

Zaangażowanie osobiste a wiek badanych nauczycielek

\begin{tabular}{|c|c|c|c|}
\hline Wiek & $\mathrm{N}$ & Srednia ranga & Suma rang \\
\hline 25-35 lat & 122 & 88.42 & 10787.00 \\
\hline 36-45 lat & 60 & 97.77 & 5866.00 \\
\hline Ogółem & 182 & & \\
\hline
\end{tabular}

Źródło: Opracowanie własne 
Tabela 8.

Całkowite wypalenie a wiek badanych nauczycielek

\begin{tabular}{|c|c|c|c|}
\hline Wiek & N & Średnia ranga & Suma rang \\
\hline $25-35$ lat & 122 & 82.60 & 10077.00 \\
\hline $36-45$ lat & 60 & 109.60 & 6576.00 \\
\hline Ogółem & 182 & & \\
\hline
\end{tabular}

Źródło: Opracowanie własne

\section{STAŻ PRACY A WYPALENIE ZAWODOWE}

Przeprowadzone badanie dostarcza dowodów, że nauczycielki z dłuższym stażem $\mathrm{w}$ większym stopniu są podatne na wypalenie zawodowe. $\mathrm{Z}$ uzyskanych wyników (tabele 9-12) wynika, że nauczycielki ze stażem pracy 16-20 lat w wymiarach wypalenia zawodowego takich jak wypalenie emocjonalne, depersonalizacja oraz w przypadku całkowitego wypalenia wykazują wyższy poziom wypalenia od młodszych stażem pracy nauczycielek, przy czym w przypadku wypalenia emocjonalnego $\left(\mathrm{H}_{\text {Kruskala-Wallisa }}=13,581 ; \mathrm{df}=3\right.$; $\mathrm{p}=0,004)$ różnice są istotne statystycznie. W przypadku zaangażowania osobistego wyższy wskaźnik charakteryzuje nauczycielki o stażu pracy od 1 do 5 lat.

Tabela 9.

Wypalenie emocjonalne a staż pracy badanych nauczycielek

\begin{tabular}{|c|c|c|}
\hline Staż pracy & N & Średnia ranga \\
\hline $1-5$ lat & 16 & 67.88 \\
\hline $6-10$ lat & 86 & 85.87 \\
\hline $11-15$ lat & 66 & 95.74 \\
\hline $16-20$ lat & 14 & 133.07 \\
\hline Ogółem & 182 & \\
\hline
\end{tabular}

Źródło: Opracowanie własne 
Tabela 10.

Depersonalizacja a staż pracy badanych nauczycielek

\begin{tabular}{|c|c|c|}
\hline Staż pracy & N & Średnia ranga \\
\hline 1-5 lat & 16 & 79.50 \\
\hline 6-10 lat & 86 & 84.17 \\
\hline 11-15 lat & 66 & 98.56 \\
\hline 16-20 lat & 14 & 116.93 \\
\hline Ogółem & 182 & \\
\hline
\end{tabular}

Źródło: Opracowanie własne

Tabela 11.

Zaangażowanie osobiste a staż pracy badanych nauczycielek

\begin{tabular}{|c|c|c|}
\hline Staż pracy & N & Średnia ranga \\
\hline 1-5 lat & 16 & 104.13 \\
\hline 6-10 lat & 86 & 93.08 \\
\hline 11-15 lat & 66 & 86.29 \\
\hline 16-20 lat & 14 & 91.93 \\
\hline Ogółem & 182 & \\
\hline
\end{tabular}

Źródło: Opracowanie własne

Tabela 12.

Całkowite wypalenie zawodowe a staż pracy badanych nauczycielek

\begin{tabular}{|c|c|c|}
\hline Staż pracy & N & Średnia ranga \\
\hline 1-5 lat & 16 & 83.75 \\
\hline 6-10 lat & 86 & 86.06 \\
\hline 11-15 lat & 66 & 94.92 \\
\hline 16-20 lat & 14 & 117.64 \\
\hline Ogółem & 182 & \\
\hline
\end{tabular}

Źródło: Opracowanie własne 


\section{Posiadane WYKSZTAŁCENIE A WYPALENIE ZAWODOWE}

Przeprowadzone badanie nie dostarcza dowodów, by posiadanie dyplomu licencjata czy też magistra determinowało podatność na wypalenie zawodowe. Z uzyskanych wyników (tabele 13-16) wynika, że nauczycielki legitymujące się dyplomem magistra $\mathrm{w}$ wymiarach wypalenia zawodowego takich jak: wypalenie emocjonalne oraz depersonalizacja charakteryzują się wyższym poziomem wypalenia. Natomiast nauczycielki z licencjatem mają wyższe wyniki $\mathrm{w}$ wymiarach wypalenia zawodowego takich jak zaangażowanie osobiste i całkowitym wypaleniemi całkowitym wypaleniem. W przypadku zaangażowania osobistego różnica jest istotna statystycznie $(\mathrm{U}=3160, \mathrm{p}=0,009)$.

Tabela 13

Wypalenie emocjonalne a wykształcenie badanych nauczycielek

\begin{tabular}{|c|c|c|c|}
\hline Posiadane wykształcenie & N & Średnia ranga & Suma rang \\
\hline wyższe zawodowe (licencjat) & 102 & 90.75 & 9257.00 \\
\hline wyższe magisterskie lub doktorskie & 80 & 92.45 & 7396.00 \\
\hline Ogółem & 182 & & \\
\hline
\end{tabular}

Źródło: Opracowanie własne

Tabela 14.

Depersonalizacja a wykształcenie badanych nauczycielek

\begin{tabular}{|c|c|c|c|}
\hline Posiadane wykształcenie & N & Średnia ranga & Suma rang \\
\hline wyższe zawodowe (licencjat) & 102 & 90.26 & 9207.00 \\
\hline wyższe magisterskie lub doktorskie & 80 & 93.08 & 7446.00 \\
\hline Ogółem & 182 & & \\
\hline
\end{tabular}

Źródło: Opracowanie własne

Tabela 15.

Zaangażowanie osobiste a wykształcenie badanych nauczycielek

\begin{tabular}{|c|c|c|c|}
\hline Posiadane wykształcenie & N & Średnia ranga & Suma rang \\
\hline wyższe zawodowe (licencjat) & 102 & 100.52 & 10253.00 \\
\hline wyższe magisterskie lub doktorskie & 80 & 80.00 & 6400.00 \\
\hline Ogółem & 182 & & \\
\hline
\end{tabular}

Źródło: Opracowanie własne 
Tabela 16.

Całkowite wypalenie zawodowe a wykształcenie badanych nauczycielek

\begin{tabular}{|c|c|c|c|}
\hline Posiadane wykształcenie & N & Średnia ranga & Suma rang \\
\hline wyższe zawodowe (licencjat) & 102 & 94.32 & 9621.00 \\
\hline $\begin{array}{c}\text { wyższe magisterskie lub dok- } \\
\text { torskie }\end{array}$ & 80 & 87.90 & 7032.00 \\
\hline Ogółem & 182 & & \\
\hline
\end{tabular}

Źródło: Opracowanie własne

\section{STOPIEŃ AWANSU ZAWODOWEGo A WYPALENIE ZAWODOWE}

W przypadku zmiennej niezależnej stopień awansu zawodowego przeprowadzone badanie dostarcza dowodów, że ta właśnie cecha determinuje podatność na wypalenie zawodowe. Z uzyskanych wyników (tabele 17-20) wynika, że nauczycielki mianowane w wymiarach wypalenia zawodowego takich jak wypalenie emocjonalne $\left(\mathrm{H}_{\text {Kruskala-Wallisa }}=11,623 ; \mathrm{df}=2 ; \mathrm{p}=0,003\right)$, depersonalizacja $\left(\mathrm{H}_{\text {Kruskala-Wallisa }}=11,172 ; \mathrm{df}=2 ; \mathrm{p}=0,004\right)$ oraz całkowite wypalenie zawodowe $\left(\mathrm{H}_{\text {Kruskala-Wallisa }}=8,504 ; \mathrm{df}=2 ; \mathrm{p}=0,014\right)$ różnią się istotnie statystycznie od pozostałych badanych nauczycielek. Natomiast nauczycielki stażystki wykazują wyższy poziom wypalenia w przypadku zaangażowania osobistego. W tym przypadku różnica także jest istotna statystycznie $\left(\mathrm{H}_{\text {Kruskala-Wallisa }}=9,123 ; \mathrm{df}=2 ; \mathrm{p}=0,010\right)$.

Tabela 17.

Wypalenie emocjonalne a stopień awansu zawodowego badanych nauczycielek

\begin{tabular}{|c|c|c|}
\hline Stopień awansu zawodowego & N & Średnia ranga \\
\hline stażysta & 80 & 82.20 \\
\hline kontraktowy & 52 & 83.19 \\
\hline mianowany & 48 & 112.25 \\
\hline Ogółem & 180 & \\
\hline
\end{tabular}

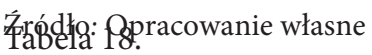


Depersonalizacja a stopień awansu zawodowego badanych nauczycielek

\begin{tabular}{|c|c|c|}
\hline Stopień awansu zawodowego & N & Średnia ranga \\
\hline stażysta & 80 & 89.10 \\
\hline kontraktowy & 52 & 75.19 \\
\hline mianowany & 48 & 109.42 \\
\hline Ogółem & 180 & \\
\hline
\end{tabular}

Źródło: Opracowanie własne

Tabela 19.

Zaangażowanie osobiste a wykształcenie badanych nauczycielek

\begin{tabular}{|c|c|c|}
\hline Stopień awansu zawodowego & N & Srednia ranga \\
\hline stażysta & 80 & 102.55 \\
\hline kontraktowy & 52 & 75.00 \\
\hline mianowany & 48 & 87.21 \\
\hline Ogółem & 180 & \\
\hline
\end{tabular}

Źródło: Opracowanie własne

Tabela 20.

Całkowite wypalenie zawodowe a stopień awansu zawodowego badanych nauczycielek

\begin{tabular}{|c|c|c|}
\hline Stopień awansu zawodowego & N & Średnia ranga \\
\hline stażysta & 80 & 92.08 \\
\hline kontraktowy & 52 & 74.77 \\
\hline mianowany & 48 & 104.92 \\
\hline Ogółem & 180 & \\
\hline
\end{tabular}

Źródło: Opracowanie własne 


\section{MIEJSCOWOŚĆ, W JAKIEJ ZNAJDUJE SIĘ PLACÓWKA OŚWIATOWA PRACY A WYPALENIE ZAWODOWE}

W przypadku zmiennej niezależnej typ miejscowości, w jakiej znajduje się szkoła, przeprowadzone badanie nie dostarczyło dowodów, by ta cecha determinowała istotnie statystycznie podatność na wypalenie zawodowe. Uzyskane wyniki (tabele 21-24) wskazują, że nauczycielki pracujące na wsi charakteryzują się wyższym poziomem wypalenia zawodowego od pozostałych nauczycielek, jednak jest to różnica nieistotna statystycznie.

Tabela 21.

Wypalenie emocjonalne a lokalizacja placówki oświatowej

\begin{tabular}{|c|c|c|}
\hline Lokalizacja placówki oświatowej & N & Średnia ranga \\
\hline wieś & 70 & 98.96 \\
\hline miasto do 100 tys. & 66 & 93.59 \\
\hline miasto powyżej 100 tys. & 46 & 77.15 \\
\hline Ogółem & 182 & \\
\hline
\end{tabular}

Źródło: Opracowanie własne

Tabela 22.

Depersonalizacja a lokalizacja placówki oświatowej

\begin{tabular}{|c|c|c|}
\hline Lokalizacja placówki oświatowej & N & Średnia ranga \\
\hline wieś & 70 & 100.87 \\
\hline miasto do 100 tys. & 66 & 85.53 \\
\hline miasto powyżej 100 tys. & 46 & 85.80 \\
\hline Ogółem & 182 & \\
\hline
\end{tabular}

Źródło: Opracowanie własne

Tabela 23.

Zaangażowanie osobiste a lokalizacja placówki oświatowej

\begin{tabular}{|c|c|c|}
\hline Lokalizacja placówki oświatowej & N & Średnia ranga \\
\hline wieś & 70 & 96.44 \\
\hline miasto do 100 tys. & 66 & 95.14 \\
\hline miasto powyżej 100 tys. & 46 & 78.76 \\
\hline Ogółem & 182 & \\
\hline
\end{tabular}

Źródło: Opracowanie własne 
Tabela 24.

Całkowite wypalenie a lokalizacja placówki oświatowej

\begin{tabular}{|c|c|c|}
\hline Lokalizacja placówki oświatowej & N & Srednia ranga \\
\hline wieś & 70 & 100.87 \\
\hline miasto do 100 tys. & 66 & 91.38 \\
\hline miasto powyżej 100 tys. & 46 & 77.41 \\
\hline Ogółem & 182 & \\
\hline
\end{tabular}

Źródło: Opracowanie własne

\section{SAMOOCENA - SES ROSENBERGA A WYBRANE CECHY SPOŁECZNO-ZAWODOWE BADANYCH NAUCZYCIELEK}

W przypadku zmiennej zależnej - samoocena mierzonej skalą Rosenberga okazało się, że poza stopniem awansu zawodowego $\left(\mathrm{H}_{\text {Kruskala-Wallisa }}=6,204\right.$; $\mathrm{df}=2 ; \mathrm{p}=0,045)$ żadna inna zmienna niezależna nie determinuje poziomu samooceny badanych nauczycielek. Szczegółowe wyniki zawierają tabele 25-24.

Tabela 25.

Poziom samooceny SES Rosenberga a typ placówki oświatowej

\begin{tabular}{|c|c|c|c|}
\hline Typ placówki oświatowej & $\mathrm{N}$ & Średnia ranga & Suma rang \\
\hline Przedszkole & 86 & 94.36 & 8115.00 \\
\hline Szkoła podstawowa & 96 & 88.94 & 8538.00 \\
\hline Ogółem & 182 & & \\
\hline
\end{tabular}

Źródło: Opracowanie własne

Tabela 26.

Poziom samooceny SES Rosenberga a wiek badanych nauczycielek

\begin{tabular}{|c|c|c|c|}
\hline Wiek & N & Średnia ranga & Suma rang \\
\hline $25-35$ lat & 122 & 95.29 & 11625.00 \\
\hline $36-45$ lat & 60 & 83.80 & 5028.00 \\
\hline Ogółem & 182 & & \\
\hline
\end{tabular}

Źródło: Opracowanie własne 
Tabela 27.

Poziom samooceny SES Rosenberga a staż pracy badanych nauczycielek

\begin{tabular}{|c|c|c|}
\hline Staż pracy & N & Średnia ranga \\
\hline $1-5$ lat & 16 & 82.38 \\
\hline $6-10$ lat & 86 & 95.01 \\
\hline $11-15$ lat & 66 & 93.20 \\
\hline $16-20$ lat & 14 & 72.36 \\
\hline Ogółem & 182 & \\
\hline
\end{tabular}

Źródło: Opracowanie własne

Tabela 28.

Poziom samooceny SES Rosenberga a wykształcenie badanych nauczycielek

\begin{tabular}{|c|c|c|c|}
\hline Posiadane wykształcenie & N & Średnia ranga & Suma rang \\
\hline wyższe zawodowe (licencjat) & 102 & 96.13 & 9805.00 \\
\hline wyższe magisterskie lub doktorskie & 80 & 85.60 & 6848.00 \\
\hline Ogółem & 182 & & \\
\hline
\end{tabular}

Źródło: Opracowanie własne

Tabela 29.

Poziom samooceny SES Rosenberga a stopień awansu zawodowego badanych nauczycielek

\begin{tabular}{|c|c|c|}
\hline Stopień awansu zawodowego & N & Średnia ranga \\
\hline stażysta & 80 & 85.93 \\
\hline kontraktowy & 52 & 105.42 \\
\hline mianowany & 48 & 81.96 \\
\hline Ogółem & 180 & \\
\hline
\end{tabular}

Źródło: Opracowanie własne 
Tabela 30 .

Poziom samooceny SES Rosenberga a lokalizacja placówki oświatowej

\begin{tabular}{|c|c|c|}
\hline Lokalizacja placówki oświatowej & N & Średnia ranga \\
\hline wieś & 70 & 81.16 \\
\hline miasto do 100 tys. & 66 & 93.11 \\
\hline miasto powyżej 100 tys. & 46 & 104.93 \\
\hline Ogółem & 182 & \\
\hline
\end{tabular}

Źródło: Opracowanie własne

\section{WEWNĘTRZNE KORELACJE MIĘDZY WYMIARAMI WYPALENIA ZAWODOWEGO}

Wartość współczynników korelacji (r Pearsona) pomiędzy trzema wymiarami wypalenia zawodowego pokazuje, że niskim wartościom jednych wymiarów wypalenia towarzyszą niskie wartości innych wymiarów wypalenia zawodowego (korelacje dodatnie). Wart podkreślenia jest fakt, że najsilniej powiązane są ze sobą wymiar depersonalizacji z wypaleniem emocjonalnym $(r=0,450)$ oraz zaangażowaniem osobistym $(r=0,412)$. Szczegółowe wyniki zawiera tabela 31 .

Tabela 31.

Wartości korelacji współczynnika $r$ Pearsona pomiędzy trzema komponentami wypalenia zawodowego $(\mathrm{N}=182)$

\begin{tabular}{|c|c|c|}
\hline & $\begin{array}{c}\text { Wartość komponentu } \\
\text { depersonalizacja }\end{array}$ & $\begin{array}{c}\text { Wartość komponentu } \\
\text { zaangażowanie osobiste }\end{array}$ \\
\hline $\begin{array}{c}\text { wartość komponentu wypalenie } \\
\text { emocjonalne }\end{array}$ & 0,450 & 0,311 \\
\hline $\mathrm{p}$ & 0,000 & 0,000 \\
\hline $\begin{array}{c}\text { wartość komponentu } \\
\text { depersonalizacja }\end{array}$ & & 0,412 \\
\hline $\mathrm{p}$ & & 0,000 \\
\hline
\end{tabular}

Źródło: Opracowanie własne 


\section{WEWNĘTRZNE KORELACJE MIĘDZY WYMIARAMI WYPALENIA ZAWODOWEGO A SAMOOCENA - SES ROSENBERGA}

Wartość współczynników korelacji (r Pearsona) pomiędzy trzema wymiarami wypalenia zawodowego a poczuciem samooceny pokazuje, że wysokim wartościom skali samooceny Rosenberga towarzyszą niskie wartości komponentów wypalenia zawodowego, co oznacza, że niskiemu poczuciu wypalenia zawodowego towarzyszy wysoka samoocena. Najsilniej powiązane są ze sobą wymiar zaangażowania osobistego i SES $(r=-0,438)$. Szczegółowe wyniki zawiera tabela 32 .

Tabela 32.

Wartości korelacji współczynnika $r$ Pearsona pomiędzy trzema wymiarami wypalenia zawodowego a poczuciem samooceny $(\mathrm{N}=182)$

\begin{tabular}{|c|c|}
\hline $\begin{array}{c}\text { wartość komponentu } \\
\text { wypalenie emocjonalne }\end{array}$ & Wartość SES \\
\hline $\mathrm{p}$ & 0,164 \\
\hline $\begin{array}{c}\text { wartość komponentu } \\
\text { depersonalizacja }\end{array}$ & $-0,197$ \\
\hline $\mathrm{p}$ & 0,000 \\
\hline $\mathrm{p}$ & $-0,438$ \\
\hline zaangażowanie osobiste & 0,000 \\
\hline
\end{tabular}

Źródło: Opracowanie własne

\section{WNIOSKI Z BADAŃ}

Głównym celem przedstawionych badań było empiryczne rozpoznanie zjawiska wypalenia zawodowego u nauczycielek wychowania przedszkolnego i edukacji wczesnoszkolnej oraz ustalenie związków wymiarów wypalenia zawodowego $\mathrm{z}$ samooceną oraz z wybranymi zmiennymi społeczno-demograficznymi. 
Ogólne pytanie badawcze brzmiało: czy i jakie różnice w poziomie wypalenia zawodowego nauczycielek definiowane w trzech wymiarach występują u osób o określonych cechach demograficznych, społecznych oraz o określonym poziomie samooceny?

Do celów metodologicznych wyodrębniono następujące pytania badawcze szczegółowe:

1. Jaki jest związek między typem placówki oświatowej, w jakiej pracują badane nauczycielki, a poszczególnymi wymiarami wypalenia zawodowego?

2. W jakim stopniu wiek badanych determinuje poszczególne wymiary wypalenia zawodowego nauczycielek?

3. W jakim stopniu staż pracy determinuje poszczególne wymiary wypalenia zawodowego nauczycielek?

4. W jakim stopniu posiadane wykształcenie determinuje poszczególne wymiary wypalenia zawodowego nauczycielek?

5. W jakim stopniu posiadany stopień awansu zawodowego determinuje poszczególne wymiary wypalenia zawodowego nauczycielek?

6. W jakim stopniu lokalizacja placówki oświatowej determinuje poszczególne wymiary wypalenia zawodowego nauczycielek?

7. W jakim stopniu rodzaj placówki oświatowej, w jakiej pracują nauczycielki, determinuje poziom samooceny nauczycielek?

8. W jakim stopniu wiek determinuje poziom samooceny nauczycielek?

9. W jakim stopniu staż pracy determinuje poziom samooceny nauczycielek?

10. W jakim stopniu posiadane wykształcenie determinuje poziom samooceny nauczycielek?

11. W jakim stopniu posiadany stopień awansu zawodowego wpływa na poziom samooceny nauczycielek?

12. W jakim stopniu lokalizacja placówki oświatowej determinuje poziom samooceny nauczycielek?

13. Jaki jest związek między poziomem samooceny badanych nauczycielek a poszczególnymi wymiarami wypalenia zawodowego?

Uzyskane wyniki weryfikacji hipotez przedstawiono w tabeli 33 i 34 . 
Tabela 33.

Rezultat weryfikacji hipotez badawczych dotyczących zmiennej zależnej wypalenie zawodowe ${ }^{1}$

\begin{tabular}{|c|c|c|c|c|}
\hline $\begin{array}{c}\text { Lp. } \\
\text { hipotezy }\end{array}$ & Hipoteza & $\begin{array}{c}\text { Wypalenie } \\
\text { emocjonalne }\end{array}$ & Depersonalizacja & $\begin{array}{c}\text { Zaangażowanie } \\
\text { osobiste }\end{array}$ \\
\hline 1. & $\begin{array}{c}\text { Istnieje związek między typem } \\
\text { placówki oświatowej, w jakiej } \\
\text { pracują badane nauczycielki, } \\
\text { a poszczególnymi wymiarami } \\
\text { wypalenia zawodowego }\end{array}$ & odrzucona & odrzucona & $\begin{array}{l}\text { zaakceptowana } \\
\text { Wyższy poziom } \\
\text { u nauczycielek } \\
\text { wychowania } \\
\text { przedszkolnego }\end{array}$ \\
\hline 2. & $\begin{array}{l}\text { Istnieje związek między } \\
\text { wiekiem badanych } \\
\text { a poszczególnymi wymiarami } \\
\text { wypalenia zawodowego }\end{array}$ & $\begin{array}{c}\text { zaakceptowana } \\
\text { Wyższy poziom } \\
\text { u nauczycielek w wieku } \\
\text { 36-45 lat } \\
\end{array}$ & $\begin{array}{c}\text { zaakceptowana } \\
\text { Wyższy poziom } \\
\text { u nauczycielek } \\
\text { w wieku 36-45 lat }\end{array}$ & odrzucona \\
\hline 3. & $\begin{array}{c}\text { Istnieje związek między stażem } \\
\text { pracy a poszczególnymi } \\
\text { wymiarami wypalenia } \\
\text { zawodowego }\end{array}$ & $\begin{array}{l}\text { zaakceptowana } \\
\text { Wyższy poziom } \\
\text { u nauczycielek o stażu } \\
\text { pracy 16-20 lat }\end{array}$ & odrzucona & odrzucona \\
\hline 4. & $\begin{array}{c}\text { Istnieje związek między } \\
\text { posiadanym wykształceniem } \\
\text { a poszczególnymi wymiarami } \\
\text { wypalenia zawodowego }\end{array}$ & odrzucona & odrzucona & $\begin{array}{l}\text { zaakceptowana } \\
\text { Wyższy poziom } \\
\text { u nauczycielek } \\
\text { z licencjatem }\end{array}$ \\
\hline 5. & $\begin{array}{c}\text { Istnieje związek między } \\
\text { posiadanym stopniem awansu } \\
\text { zawodowego a poszczególnymi } \\
\text { wymiarami wypalenia } \\
\text { zawodowego } \\
\end{array}$ & $\begin{array}{l}\text { zaakceptowana } \\
\text { Wyższy poziom } \\
\text { u nauczycielek } \\
\text { z mianowaniem }\end{array}$ & $\begin{array}{l}\text { zaakceptowana } \\
\text { Wyższy poziom } \\
\text { u nauczycielek } \\
\text { z mianowaniem }\end{array}$ & $\begin{array}{l}\text { zaakceptowana } \\
\text { Wyższy poziom } \\
\text { u nauczycielek } \\
\text { - stażystek }\end{array}$ \\
\hline 6. & $\begin{array}{c}\text { Istnieje związek miédzy } \\
\text { lokalizacją placówki oświatowej } \\
\text { a poszczególnymi wymiarami } \\
\text { wypalenia zawodowego }\end{array}$ & odrzucona & odrzucona & odrzucona \\
\hline 13. & $\begin{array}{l}\text { Istnieje związek między } \\
\text { poziomem samooceny } \\
\text { badanych nauczycielek a } \\
\text { poszczególnymi wymiarami } \\
\text { wypalenia zawodowego }\end{array}$ & $\begin{array}{c}\text { zaakceptowana } \\
\text { Im niższy poziom } \\
\text { samooceny, tym wyższe } \\
\text { wypalenie zawodowe } \\
\text { w wymiarze wypalenie } \\
\text { emocjonalne }\end{array}$ & $\begin{array}{l}\text { zaakceptowana } \\
\text { Im niższy poziom } \\
\text { samooceny, tym } \\
\text { wyższe wypalenie } \\
\text { zawodowe } \\
\text { w wymiarze } \\
\text { depersonalizacja }\end{array}$ & $\begin{array}{c}\text { zaakceptowana } \\
\text { Im niższy poziom } \\
\text { samooceny, tym } \\
\text { wyższe wypalenie } \\
\text { zawodowe } \\
\text { w wymiarze } \\
\text { zaangażowanie } \\
\text { osobiste } \\
\end{array}$ \\
\hline
\end{tabular}

${ }^{1}$ W tabeli zachowano pierwotną numerację pytań badawczych wymienionych w części „Pytania badawcze”.

Źródło: Opracowanie własne 
Tabela 34.

Rezultat weryfikacji hipotez badawczych dotyczących zmiennej zależnej samoocena ${ }^{1}$

\begin{tabular}{|c|c|c|}
\hline $\begin{array}{c}\text { Lp. } \\
\text { hipotezy }\end{array}$ & Hipoteza & \\
\hline 7. & $\begin{array}{l}\text { Istnieje związek między rodzajem placówki oświatowej } \\
\text { a poziomem samooceny nauczycielek. }\end{array}$ & odrzucona \\
\hline 8. & $\begin{array}{l}\text { Istnieje związek między wiekiem a poziomem } \\
\text { samooceny nauczycielek. }\end{array}$ & odrzucona \\
\hline 9. & $\begin{array}{l}\text { Istnieje związek między stażem pracy a poziomem } \\
\text { samooceny nauczycielek. }\end{array}$ & odrzucona \\
\hline 10. & $\begin{array}{l}\text { Istnieje związek między posiadanym wykształceniem } \\
\text { a poziomem samooceny nauczycielek. }\end{array}$ & odrzucona \\
\hline 11. & $\begin{array}{l}\text { Istnieje związek między posiadanym stopniem awansu } \\
\text { zawodowego a poziomem samooceny nauczycielek. }\end{array}$ & $\begin{array}{c}\text { zaakceptowana } \\
\text { Wyższy poziom samooceny } \\
\text { u nauczycielek z mianowaniem }\end{array}$ \\
\hline 12. & $\begin{array}{c}\text { Istnieje związek między lokalizacją placówki } \\
\text { oświatowej a poziomem samooceny nauczycielek. }\end{array}$ & odrzucona \\
\hline
\end{tabular}

${ }^{1}$ W tabeli zachowano pierwotną numerację pytań badawczych wymienionych w części „Pytania badawcze”.

Źródło: Opracowanie własne

Z przeprowadzonych badań wynika, że w badanej grupie nauczycielek znalazły się nauczycielki zróżnicowane, jeśli chodzi o wypalenie zawodowe. Niski poziom wypalenia reprezentowało $29,7 \%$ badanych, przeciętny $41,7 \%$, wysoki zaś 28,6\%. Zmienne socjo-demograficzne takie jak wiek, staż pracy, wykształcenie, stopień awansu zawodowego, miejsce pracy, miały zróżnicowany wpływ na wystąpienie objawów wypalenia w badanej grupie. Jedynie lokalizacja placówki oświatowej (wieś, małe miasto, duże miasto) nie oddziaływała w ogóle na poziom wypalenia.

Zależność pomiędzy poziomem kształcenia (przedszkolny, wczesnoszkolny), wiekiem badanych, ich stażem pracy, poziomem wykształcenia a wypaleniem zawodowym nie pozwala w badanej grupie na wykreślenie trwałego trendu, zależności pozwalającej jednoznacznie zinterpretować uzyskane wyniki. Czynniki socjo-demograficzne nie mają również wysokiego wpływu 
na samoocenę badanej grupy nauczycielek. Nie ma zauważalnych różnic między poszczególnymi podgrupami a wartością wskaźnikową zmiennej samoocena. Znakomita większość (72\%) badanych nauczycielek osiągnęła przeciętne i ponadprzeciętne wyniki w teście samooceny SES Rosenberga. Po weryfikacji hipotez można stwierdzić, że nauczycielki z wyższym stażem pracy miały wyższe wyniki samooceny uzyskane testem SES Rosenberga.

\section{Literatura}

Antczak, B. (2015). Niska frekwencja uczniów jako jedna z przyczyn niepowodzeń szkolnych. Journal of Modern Science, 25(2), 297-311. ISSN 1734-2031.

Bedyńska S., Brzezicka, A. (red. nauk.) (2007). Statystyczny drogowskaz. Praktyczny poradnik analizy danych w naukach społecznych na przykładach z psychologii, Wydawnictwo SWPS „Akademia”, Warszawa. ISBN 9788389281401.

Bedyńska, S., Cypryańska, M. (red.) (2013). Statystyczny drogowskaz 2. Praktyczne wprowadzenie do analizy wariancji, Wydawnictwo Akademickie "Sedno", Warszawa. ISBN 9788362443239.

Jurzysta, K. (2017). Pedagogika kultury w systemie wspótczesnej edukacji. Journal of Modern Science, 35(4), 11-32. https://doi.org/10.13166/jms/84814. ISSN 1734-2031.

Koseła, K., Utzig, K. (1980). Skalowanie wielowymiarowe - zastosowania uprawnione i nieuprawnione. Studia Socjologiczne Nr 2. ISSN 0039-3371.

Marek, T. (1989). Analiza skupień w badaniach empirycznych. Metody SAHN. PWN, Warszawa. ISBN 8301095377.

Noworol, Cz. (1989). Analiza skupień w badaniach empirycznych. Rozmyte modele hierarchiczne, PWN, Warszawa. ISBN 8301100095.

Plichta, P. (2015). Wypalenie zawodowe i poczucie sensu życia pedagogów specjalnych, Oficyna Wydawnicza ATUT - Wrocławskie Wydawnictwo Oświatowe, Wrocław. ISBN 9788379771141.

Strzyżewska, M., Rószkiewicz, M. (2002). Analizy marketingowe. Difin, Warszawa, s. 288. ISBN $837251271 X$. 